\title{
SOCIAL ENGINEERING IN THE PROGRAM OF MATURATION OF AGE MARRIAGE
}

\author{
Ermi Suhasti Syafei \& Ihab Habudin* \\ Universitas Islam Negeri (UIN) Sunan Kalijaga Yogyakarta \\ Email: ermi.suhasti@yahoo.co.id
}

\begin{abstract}
The tradition of early marriage is a classic social problem faced by several regions. In the past four years this tradition has declined significantly, especially in Gunung Kidul, Yogyakarta. This achievement was influenced by the existence of a creative program in the form of a program of maturation of age marriage. This article explains the process of procuring a program of maturation of age marriage in Gedangsari Subdistrict, Gunungkidul Regency. The results of the study indicate the provision of a program of maturation of age marriage to prevent the occurrence of child marriage involving various related organizations and institutions. This program is very effective in reducing the rate of child marriage in Gedangsari. This program can be interpreted as social engineering so that social changes occur in the community through the process of adaptation, efforts to achieve goals, integration and latency of systems and social structures. Social engineering through law enforcement is built on rational and legal (rational-legal) arguments.
\end{abstract}

Keywords: tradition of early marriage, social engineering, maturation of marriage age, structural functionalism, legal rationality

\section{Introduction}

At the end of 2013 to June 2015, there were 355 applications for marriage dispensation ${ }^{1}$ which was granted by the Wonosari Religious Court. That is why, there are 355 child-age marriages taking place in Gunungkidul in just one and a half years. Among other things, the age of child marriages is 14 years old (female) and 15 years old (male)). ${ }^{2}$ The high number of cases of child age marriage has moved the Regent to issue a policy so that marriage is based on the applicable minimum age for marriage. ${ }^{3}$ In 2015, Badingah, the Regent of Gunungkidul Regency in Yogyakarta issued Regulations of Regent of Gunungkidul Number 36 of 2015 concerning Prevention of Marriage at the Age of Children. This policy was issued in connection with a fairly high age child

\footnotetext{
* Dosen Fakultas Syariah dan Hukum Universitas Islam Negeri (UIN) Sunan Kalijaga Yogyakarta.

1 Marriage dispensation is an application submitted to the Religious Court to give permission for parties who want to get married but are obstructed by the age who have not reached the minimum age of marriage as determined by the relevant laws and regulations.

2" Regent Regulation Number 36 of 2015 concerning Prevention of Marriage at the Age of Children "see in https://bpmpkbgunungkidul.wordpress.com/2015/11/03/peraturan-bupati-nomor-36tahun-2015-tentang-pencegahan-perkawinan-pada-usia-anak/. Accessed 10 April 2018.

${ }^{3}$ In the marriage law, for example, someone who wants to have a marriage is at least 16 years old for women and 19 years for men. See Law No. 1 of 1974 concerning Marriage.
} 
marriage case. This policy received appreciation from various parties, including Non-governmental organization, ${ }^{4}$ who saw it as a breakthrough in making social changes in Gunungkidul Regency. This policy was then followed up with various programs in each sub-district in Gunungkidul.

One interesting fact to be observed is that three years before the Regent of Gunungkidul issued Regent Regulation No. 36 of 2015 concerning Prevention of Marriage at the Age of Children, various elements of the community in Gedangsari Subdistrict had begun strategic steps in "mencegah perkawinan pada usia anak" (to prevent marriage at the age of children) through marriage age. It can be said that Gedangsari Subdistrict became a pioneer in the "pencegahan perkawinan pada usia anak" (prevention of marriage at the age of children) movement in Gunungkidul District, before other sub-districts promoted it.

The marriage age maturation program in Gedangsari Subdistrict is driven by the fact that there are high rates of child marriage. Based on the data released in 2015, Gedangsari Subdistrict has a poor record regarding child age marriages - the rate of child marriage at Gedangsari is quite large with a trend that continues to increase every year. This condition inhibits the realization of a sakinah (love and passion) family which is the goal of marriage and can cause social problems such as divorce, domestic violence, dropping out of school, poverty, and so on.

This condition was then addressed by various institutions and community elements in Gedangsari District. It began with the Office of Religious Affairs (KUA) of Gedangsari together with a number of government agencies and NonGovernmental Organization (NGOs) to carry out a "social engineering" so that child marriage problems could be overcomed, as well as provisions in legislation concerning the minimum age for marriage age can be fulfilled. The form of "social engineering" is to seriously and consistently seek a marriage age maturation program since 2013 through (1) making a joint agreement to overcome the 2013 Gedangsari sub-district social problems; (2) Dukuh Declaration in Gedangsari Subdistrict Free of Child Age Marriage in 2014; (3) Gedangsari Award for villages that have succeeded in showing the lowest number of child age marriages in their village; (4) lyrical video of Ayunda Si Menik (Let's Delay Married). With the various agendas of the marriage age maturity program, the Gedangsari community has proven to be a pioneer in the prevention of child marriage.

As one of the outermost sub-districts in Gunungkidul Regency, the emergence of Gedangsari as the main actor in seeking social change in overcoming child marriage problems is very interesting to study. Not only

4 Rifka Annisa, for example, appreciates the Gunungkidul Regent Regulation by participating in socializing it. See "Socialization of Regent Regulation Number 36 of 2015 concerning Prevention of Marriage at the Age of Children" in http://rifka-annisa.org/id/berita/beritaumum/item/419-sosialisasi-peraturan-bupati-nomor-36-tahun-2015-tentang-pencegahan-perkawinan-padausia-anak. Accessed on April 9, 2018. 
because in all limitations - such as socio-economic conditions - education and geography - they are able to make social changes, but also in reality the social changes actually occur even quite significantly. Childhood age rates drop drastically. The head of the Religious Affairs Office of Gedangsari Subdistrict revealed that in the past few years the number of marriages of children was no more than five.

On the other hand, the maturation program of marriage age actually reflects the engineering of several institutions and elements of society in upholding Islamic law, especially with regard to the minimum age for marriage. This provision seeks to be enforced so that law can be a means of control as well as a means of social change. The Gedangsari Subdistrict community, which is predominantly Muslim, has experienced a social shift from the community that had experienced many cases of child marriage, becoming people who have marriages within the prescribed age limit.

This article seeks to uncover the engineering of Islamic law enforcement in realizing social change in the Gedangsari Gunungkidul community of Yogyakarta from a sociological approach, specifically through analysis of structural functionalism and Max Weber's concept of the system of authority.

\section{Age of Marriage in Indonesian Legal System: Legal Reform and Discourse}

Law for adherents of positivism is a provision that has been regulated in legislation. This means that the law is a rule issued by the authorities. Adherents of the school of history argue that the law grows and develops according to the development of society. If adherents of the flow of legal positivism rely on reason, then adherents of the school of history rely on experience. Different from the two schools, the Sociological Jurisprudence school sees both, reason and experience as important. The law is then interpreted not only as a rule made by the authorities but also as a means of social development. Thus it can be said that the Sociological Jurisprudence as a result of the dialectic of the positivism of law and the school of legal history.

Roscou Pound, a follower of the Sociological Jurisprudence, who argued that law is a tool for social engineering (law as a tool of social engineering). Pound's opinion that law is not only used to perpetuate power, but also functions as a tool of engineering or social change..$^{5}$ Law is an instrument that should be used to direct people to better conditions, even if the law is needed can be used to eradicate various negative habits of society. ${ }^{6}$

Pound explained that the Sociological Jurisprudence is the main characteristic of modern law. Law in this context is consciously implemented by the community. Law is not only used to strengthen patterns and behavior in

\footnotetext{
${ }^{5}$ Rasjidi, Dasar-Dasar Filsafat Hukum, (Bandung: Citra Aditya, 1990), page. 47.

${ }^{6}$ Satjipto Rahardjo, Ilmu Hukum, (Bandung: Alumni, 1986), page. 110-111.
} 
society, but also directs it to something that is desired. At this point, the law can eliminate patterns of behavior or habits that are viewed as negative, then replace them with new patterns of behavior or habits. ${ }^{7}$ In practice, Sociological Jurisprudence sees the law in terms of its effectiveness, social impact, and social history, and places it as a doctrine as well as an institution.

Such a legal concept raises the legal paradigm not only as a rule, but also the regulation lives and develops in society. Law is not only on paper, but also must be able to be applied in society, or in other languages, to be a tool for social change. Mochtar Kusuma Atmaja explained that the use of law as a social engineering tool is commonly practiced in Indonesia, where law is used as a means to manipulate society towards a scenario of government policy. The use of such law is due to the legal position as a tool to manipulate people's behavior or attitudes in order to support better economic and social development. ${ }^{8}$

Syakmin AK's opinion, as quoted by H. Yacob Djasmani, that law as an instrument of social engineering has a positive impact in several ways, namely: (1) providing legal certainty in stability and order; (2) provide firmness about what is desired from the law; and (3) placing the law as a written regulation that is in accordance with the value (sense of justice) in society..$^{9}$ Although the law is in the form of written provisions, it does not rule out the possibility of legal reform. Updates can be carried out as long as they contain values that live and originate from the community. Syakmin, as quoted by H. Yacob Djasmani, said that legal reform must be formally formulated and must be part of the experience of the Indonesian people and nation. ${ }^{10}$

In carrying out reforms, social conditions and their effectiveness for the community must be considered. In this case, reform must be based on the distinction of two problems: (1) individual problems that are closely related to culture and community spirituality; and (2) problems related to community progress, such as company law, contract law, and so on. ${ }^{11}$

Thus, the relationship between law and society is mutual influence or reciprocity. Law can be seen as people's behavior in seeing, accepting, and understanding law as part of their human life. ${ }^{12}$ Soerjono Soekanto revealed that the law was then examined in terms of reciprocity between the law and other

${ }^{7}$ H. Yacob Djasmani, Hukum sebagai Alat Rekayasa Sosial dalam Praktik Berhukum di Indonesia, (MMH, Volume 40 No. 3 of 2011), page. 367.

${ }^{8}$ Ibid, page. 366 .

${ }^{9}$ Ibid, page. 369 .

${ }^{10}$ Ibid.

${ }^{11} \mathrm{Ibid}$, page 370 .

${ }^{12}$ Satjipto Rahardjo, Sosiologi Hukum Esai-esai Terpilih, Ufran (ed.), (Yogyakarta: Genta Publishing, 2010), page. 1. 
social symptoms. ${ }^{13}$ Therefore, the law is interpreted as a provision that regulates patterns of human or group behavior in the interaction process. ${ }^{14}$

In this context, law and society are interpreted as two inseparable things. Law is called a social institution (social institution, social institution). Law is a unity of rules which aims to fulfill basic human needs to achieve peace and ${ }^{15}$ in the social context, it is merely a doctrine, but also manifests itself in social institutions in accordance with the space and time that surrounds them. ${ }^{16} \mathrm{Up}$ to this point, it can be said that the law must be upheld and able to bring about social change.

In sociology there are two schools of theories of social change: structural functionalism and social conflict. ${ }^{17}$ The theory of structural functionalism stems from the belief that social life is sustained by the structure of society in which there are diverse sub-structures. In that diversity established structures include the diversity of functions according to one's position in the structure of a system. In an organizational structure, for example, there are individuals and groups that have different functions but still work together for one purpose. Therefore, in structural functionalism theory, individuals are considered as elements that form a system or unit.

Thus, in structural functionalism theory a structure or system is interpreted as an order consisting of interconnected sub-structures. The substructures continually form equilibrium and stability. When there are deviations, the sub-structures will try to adjust to achieve balance again (functional integration). In the context of social change, adherents of this theory consider irregularities or disruptions to the order as normal and must be controlled. Therefore, if there are events that require a change, the change must be evolutionary through controlled reform. The figures of this theory include August Comte (1798-1857), Herbert Spenser (1820-1930) Emile Durkheim (18581917), Talcott Parson (1902-1979), Robert K. Merton (1910-2003) and William F. Ogburn (1886-1959). The theory of structural functionalism received sharp criticism from adherents of the social theory of conflict. For them, social structure does not run in order as mentioned by structural functionalists. Social structure

${ }^{13}$ Soerjono Soekanto, Sosiologi: Suatu Pengantar, (Jakarta: PT. RajaGrafindo Persada, 1999), page. 13.

${ }^{14}$ Bani Syarif Maula, Sosiologi Hukum Islam di Indonesia;

Study of the Reality of Islamic Law in Configuring Social and Politics, (Yogyakarta: Aditya Media Publishing, 2010), page. 1.

${ }^{15}$ Soerjono Soekanto, et.al.,Pendekatan Sosiologi terhadap Hukum, (Jakarta: Bina Aksara, 1988), page. 9 .

${ }^{16}$ Azumardi Azra, Pergolakan Politik Islam dari Fundamentalisme, Modernisme, hingga PostEngineering, (Jakarta, Paramadina, 1996), page. 1.

${ }^{17} \mathrm{~A}$ description of the structural and social functionalism theory of conflict can be seen in Ratna Megawangi, Membiarkan Berbeda? New Viewpoint on Gender Relations, volume. 1 (Bandung: Mizan, 1999), page. 56-80 and Mansour Fakih, Analisis Gender dan Tranformasi Sosial (Yogyakarta: Pustaka Pelajar, 1996), page. 80-84. 
actually consists of conflicting or conflicting sub-structures or sub-systems. Each sub-structure has an interest (interest) and power (power) is then used to master and legitimize that power. The names often associated with this theory are Karl Marx and Ralf Dahrendorf. Apart from the debate, in today's modern society, social change cannot be separated from the actors or actors of change and the social structure that surrounds them. What individuals think, realize and do cannot be separated from their social conditions. Human consciousness and freedom cannot be separated from the process of forming individual societies. Both complement and influence each other. ${ }^{18}$

In this context Max Weber explained that social change is very dependent on the social authority system of a society. Weber mentions that there are three systems of social authority: traditional authority, charismatic authority, and rational-legal authority. Weber's opinion that the traditional authority system comes from the old belief system, while charismatic authority comes from the belief in the ability of someone who is considered to have extraordinary characteristics believed by his followers. Rational-legal authority comes from formal rationality which "includes a person's thought process in making choices about tools and objectives". According to Weber, this formal rationality was built on the basis of habits, rules, and law. ${ }^{19}$ Above that authority all social structures are formed and social systems are determined, including patterns of social change made.

The formal rationality as called Weber found its form of bureaucratic rationalization. Any new form of bureaucracy can move into a modern bureaucracy if it rests on a system of rational-legal authority. Bureaucracy cannot develop in the traditional authority system and charismatic authority system. It was in this system of rational-legal authority that modern bureaucracies developed and developed. Thus it is natural for Weber to say that a rational-legal system can only be built in modern society.

\section{Program of Maturation of Age of Marriage in Gedangsari, Gunungkidul, Yogyakarta: Rifka Annisa's Case}

\section{Profil of Gedangsari, Gunungkidul, Yogyakarta and Program description.}

Geographically, Gedangsari District is one of the outermost districts in Gunungkidul Regency. Gunungkidul is the largest district in the Special Region of Yogyakarta (DIY) with an area of approximately $1,485.36 \mathrm{~km}^{2}(46.63 \%$ of the

${ }^{18} \mathrm{KJ}$. Veeger, Realitas Sosial: Reflections on Social Philosophy on Individual-Society relations in the Historical Horizon of Sociology (Jakarta: Gramedia, 1985), page. 245.

${ }^{19}$ George Ritzer, Teori Sosiologi Modern, terj. Triwibowo B.S. (Jakarta: Kencana, 2014), page. 38-39. 
area of DIY). ${ }^{20}$ This sub-district is located in the north of Gunungkidul Regency. The distance is about $40 \mathrm{~km}$ from the city of Yogyakarta. ${ }^{21}$

Gedangsari District includes the northern zone (Baturagung area) and is located 200-700 above sea level. In the midst of hilly nature there is also a river above the land. Water sources can be excavated at a depth of 6-12 meters. The lateristic volcanic soil can be used for food crop development, horticulture, plantations, forestry, livestock, small industries, minerals, tourism and protected subordinate areas. ${ }^{22}$ This sub-district has an area: $68.145 \mathrm{~km}^{2}(4.59 \%$ of the total land area of Gunungkidul Regency). ${ }^{23}$ Administratively, this Subdistrict is divided into 7 villages, 67 hamlets, 67 Neighbourhood head

(RT), Head of Hamlets(RW) and 353 RTs. The seven villages in question are Ngalang Village, Hargomulyo, Mertelu, Tegalrejo, Watugajah, Sampang, and Serut. Gedangan Hamlet in Hargomulyo Village became the city center of Gendangsari Subdistrict until now. ${ }^{24}$

Villages in Gedangsari District are self-supporting villages (backward villages). Like other regions in Indonesia, Gedangsari District has a tropical climate - consisting of two seasons: rainy and dry. These two seasons are very influential on farmers because agricultural activities use rainfed systems - the need for watering plants depends on rainwater. Such conditions play a major role in the formation of patterns of community activity in relation to the use of labor in agriculture. People living with farm laborers, for example, will get a lot of work during the rainy season, on the contrary they will have difficulty finding money during the dry season and are forced to find other jobs.

The majority of the population of Gedangsari Subdistrict are Muslim - the percentage reaches 98.02 percent. ${ }^{25}$ Most of the residents of Gedangsari Subdistrict have farmers' livelihoods. ${ }^{26}$ As happened in several areas in

${ }^{20}$ The Central Bureau of Statistics of Gunungkidul Regency, Gunungkidul Regency in Figures (Gunungkidul Regency in Fifures) 2017 (Yogyakarta: BPS Kabupaten Gunungkidul, 2017), page. 6 .

${ }^{21}$ Gunungkidul Regency Central Bureau of Statistics, Gedangsari District in Figures 2018 (Yogyakarta: Badan Pusat Statistik Gunungkidul, 2018), page. 3.

${ }^{22}$ Gunungkidul Regency Population and Civil Registration Service, Profile of Population Development in Gunungkidul Regency in 2017 (Yogyakarta: Department of Population and Civil Registration (Disdukcapil), Gunungkidul Regency, 2017), page. 11.

${ }^{23}$ Gunungkidul Regency Central Bureau of Statistics, Gunungkidul Regency in Figures 2018 (Yogyakarta: Gunungkidul Regency Central Bureau of Statistics, 2018), page. 8.

${ }^{24}$ Gunungkidul Regency Central Bureau of Statistics, Gedangsari District in Figures 2018, page. 3-11. See also "Area" in the Gunungkidul Regency Website in the Special Region of Yogyakarta

.http://www.gunungkidulkab.go.id/D-fe1c08b042e5fe88bb64140ef3ecf89e-NR-100-0.html. Access November 25, 2018.

${ }^{25} \mathrm{Ibid}$, page. 58 .

${ }^{26}$ Can be read at "Statistik Penduduk D.I. Yogyakarta", in website kependudukan.jogjaprov. go.id. See:http://kependudukan.jogjaprov.go.id/olah.php?module=statistik\&periode=9\&jenisdata population $\&$ based $=$ employment $\&$ prop=34\&kab=03\&kec=14. Accessed on November 26, 2018. 
Gunungkidul Regency, Gedangsari Subdistrict is also inseparable from various social problems, such as poverty, low education, high divorce rates, and free promiscuity among teenagers. These problems are exacerbated by less favorable natural conditions, such as infertile land and hilly terrain.

\section{Cases of Child Marriage in Gedangsari, Gunungkidul Regency.}

In the period of 2010-2016, women aged 10 to 16 who married in Gunungkidul Regency ranked the highest five times the age of child marriage by Regency / City. The high rate of marriage at the age of children in Gunungkidul Regency compared to District / City in Yogyakarta Special Province can be seen in the following table. ${ }^{27}$

In 2017, Gunungkidul Regency also listed itself as a contributor to the highest number of child marriage ages in Yogyakarta Special Province. Central Bureau of Statistics (BPS) Yogyakarta Special Province noted that there were $12.59 \%$ of women married at less than 16 years of age and $19.30 \%$ of women were married at the age of 17-18 in Gunungkidul Regency. This figure is above the figure of Kulonprogo Regency which is one strip below which the percentage reaches $7.95 \%$ for women who are married at the age of less than 16 years and $13.54 \%$ for women who marry at the age of $17-18$ years. ${ }^{28}$

In view of the alarming conditions, Badingah, the Regent of Gunungkidul Regency, paid special attention to efforts to reduce the age rate of child marriage in the region. This is evidenced by the issuance of Gunungkidul Regent Regulation No. 36 of 2015 concerning Prevention of Marriage at the Age of Children. This regulation targets the Regional Government of Gunungkidul Regency, children, parents, the community, and all interested parties to prevent the occurrence of marriage at the age of children in the Gunungkidul Regency. ${ }^{29}$

27 Yogyakarta Provincial Statistics Agency, Welfare Statistics 2010 (Yogyakarta: Statistic Center of the Special Region of Yogyakarta, 2010), page. 17-18. Central Bureau of Statistics of Yogyakarta Special Region, People's Welfare Statistics (Welfare Statistics) 2011 (Yogyakarta: Statistic Center of the Special Region of Yogyakarta, 2011), page. 17-18. Yogyakarta Special Region Statistics Agency, 2012 People's Welfare Statistics (Welfare Statistics) (Yogyakarta: Statistic Center of the Special Region of Yogyakarta, 2012), page. 17-18. Yogyakarta Province Central Bureau of Statistics, 2013 People's Welfare Statistics (Welfare Statistics) (Yogyakarta: Statistic Center of the Special Region of Yogyakarta, 2013), page. 17-18. Yogyakarta Province Central Bureau of Statistics, 2014 People's Welfare Statistics (Welfare Statistics) (Yogyakarta: Statistic Center of the Special Region of Yogyakarta, 2014), page. 17-18. Yogyakarta Special Region Central Bureau of Statistics, 2015 People's Welfare Statistics (Yogyakarta: Yogyakarta Central Bureau of Statistics, 2015), page. 17-18. Yogyakarta Special Region Statistics Agency, 2016 People's Welfare Statistics (Yogyakarta: Central Bureau of Statistics Special Region Yogyakarta, 2016), page. 23-24.

${ }^{28}$ Central Bureau of Statistics of the Special Province of Yogyakarta, People's Welfare Statistics (WelfareStatistics)2017(Yogyakarta: Statistic Center of the Special Region of Yogyakarta, 2017), page. 75

${ }^{29}$ Article 3-8 Regulations of Regent of Gunungkidul Number 36 Year 2015 concerning Prevention of Marriage at the Age of Children. 
In practice, this regulation was then able to mobilize all elements: government, community, community organizations, and stakeholders, to commit to an agenda of change in Gunungkidul Regency, namely: reducing the rate of child marriage. The hard work of all these parties bear fruit with the declining number of child age marriages in Gunungkidul Regency. This can be seen from the decrease in the number of child marriage dispensations in the last 4 years (2014-2017). In 2014, there were 151 applicants who proposed child marriage dispensations. This figure dropped in 2015 to 109 applicants; 2016 will be 85 applicants and 2017 will be 67 applicants. ${ }^{30}$ However, it seems that all parties must continue to work hard in preventing child marriage in Gunungkidul Regency. In the latest development, the child's age marriage is still quite high. Until March 2018, applicants for child marriage dispensation have reached 35 applicants. ${ }^{31}$

If there are no hard efforts from various elements (government, family, community, and community organizations), it is not impossible that the number will continue to increase even exceeding the figures in previous years. As one of the sub-districts in Gunungkidul Regency, Gedangsari Subdistrict is also inseparable from the child marriage problems which are quite high. This child age marriage rate is from data held by the Office of Religious Affairs (KUA) of Gedangsari District specifically data released starting in 2012. The data on children's age marriage before that, cannot be verified, because according to the Office of Religious Affairs (KUA) Gedangsari employee, data manipulation occurred at that time. According to Rifka Annisa, this data manipulation was carried out by parents and hamlets by asking the Office of Religious Affairs (KUA) to falsify the age of the bride to continue the marriage. ${ }^{32}$ However, it can be said that the child marriage age before 2012 is much higher. The steps to manipulate the data were carried out by the Religious Affairs Office of Gedangsari which caused it as if there were no child age marriages, to a certain extent, the method used by residents and related parties to cover the high rate of child marriage at that time.

30" Gunungkidul Continues to Attempt to Suppress Childhood Marriage Numbers", http//:tribunjogja.com. This information can be seen or listened to via the following link: http://jogja.tribunnews.com/2018/04/16 / gunungkidul-keep-trying-pressing-number-marriage-agedini. Accessed on December 1, 2018.

31 " Child marriage age in Gunungkidul is still high", http//:kumparan.com. See:https://kumparan.com/tugujogja/pernikahan-dini-di-gunungkidul-masih-tinggi. Accessed on December 1, 2018.

32 This information was obtained from interviews with the Head of Office of Religious Affairs (KUA), Gedangsari District. 
ADHKI: Journal of Islamic Family Law

Data on Marriage at the Office of Religious Affairs (KUA),

Gedangsari District in 2012-2017

\begin{tabular}{|c|c|c|c|c|c|c|c|}
\hline \multirow[b]{2}{*}{ No. } & \multirow{2}{*}{$\begin{array}{l}\text { Village } \\
\text { Name }\end{array}$} & \multicolumn{2}{|c|}{2012} & \multicolumn{2}{|c|}{2013} & \multicolumn{2}{|c|}{2014} \\
\hline & & $\begin{array}{c}\text { Total of } \\
\text { Marriages }\end{array}$ & $\begin{array}{c}\text { Marriages } \\
\text { Child }\end{array}$ & $\begin{array}{c}\text { Total of } \\
\text { Marriages }\end{array}$ & $\begin{array}{l}\text { Marriages } \\
\text { Child }\end{array}$ & $\begin{array}{c}\text { Total of } \\
\text { Marriages }\end{array}$ & $\begin{array}{c}\text { Marriages } \\
\text { Child }\end{array}$ \\
\hline 1 & Hargomulyo & 72 & 3 & 73 & 2 & 48 & 0 \\
\hline 2 & Mertelu & 42 & 1 & 36 & 0 & 35 & 0 \\
\hline 3 & Watugajah & 42 & 0 & 37 & 3 & 43 & 0 \\
\hline 4 & Ngalang & 72 & 2 & 62 & 2 & 61 & 1 \\
\hline 5 & Sampang & 26 & 0 & 32 & 1 & 31 & 1 \\
\hline 6 & Serut & 60 & 1 & 56 & 0 & 40 & 1 \\
\hline 7 & Tegalrejo & 72 & 3 & 79 & 1 & 67 & 3 \\
\hline & Total & 386 & 10 & 375 & 9 & 325 & 6 \\
\hline
\end{tabular}

\begin{tabular}{|c|c|c|c|c|c|c|c|}
\hline \multirow{2}{*}{ No. } & \multirow{2}{*}{$\begin{array}{c}\text { Village } \\
\text { Name }\end{array}$} & \multicolumn{2}{|c|}{2015} & \multicolumn{2}{c|}{2016} & \multicolumn{2}{c|}{2017} \\
\cline { 3 - 8 } & Total of & $\begin{array}{c}\text { Marriages } \\
\text { Child }\end{array}$ & $\begin{array}{c}\text { Total of } \\
\text { Marriages }\end{array}$ & $\begin{array}{c}\text { Marriages } \\
\text { Child }\end{array}$ & $\begin{array}{c}\text { Total of } \\
\text { Marriages }\end{array}$ & $\begin{array}{c}\text { Marriages } \\
\text { Child }\end{array}$ \\
\hline 1 & Hargomulyo & 59 & 1 & 57 & 0 & 55 & 0 \\
\hline 2 & Mertelu & 24 & 0 & 23 & 0 & 29 & 0 \\
\hline 3 & Watugajah & 35 & 0 & 21 & 0 & 27 & 0 \\
\hline 4 & Ngalang & 83 & 0 & 60 & 0 & 67 & 1 \\
\hline 5 & Sampang & 23 & 0 & 20 & 0 & 14 & 0 \\
\hline 6 & Serut & 43 & 0 & 23 & 0 & 31 & 1 \\
\hline 7 & Tegalrejo & 70 & 1 & 67 & 0 & 55 & 0 \\
\hline \multicolumn{2}{|c|}{ Total } & 337 & $\mathbf{2}$ & $\mathbf{2 7 1}$ & $\mathbf{0}$ & $\mathbf{2 7 8}$ & $\mathbf{2}$ \\
\hline
\end{tabular}

Source: Office of Religious Affairs (KUA)) Gedangsari District

The table shows the following points. First, in 2012, one year before there was an agreement with various institutions in Gedangsari Subdistrict to solve various social problems, the child marriage age rate was high. As mentioned above, the previous period of child marriage was higher. Secondly, from 20132017, the marriage rate of children has fluctuations (up and down) with decreasing relativity. This decrease was due to the incessant marriage maturation program in Gedangsari Subdistrict. Several factors cause high rates of marriage at the age of the child, for example, poverty, level of education, and promiscuity. This is confirmed by the poverty data in Gunungkidul Regency which is quite high, the education level is relatively low, as well as the promiscuity that is increasingly worrisome due to the development of information technology from the city to enter the countryside. 


\section{Program of Maturation of Age of Marriage in Gunung Kidul}

In 2012, prior to the issuance of Gunungkidul Regent Regulation Number. 36 of 2015 concerning Prevention of Marriage at the Age of Children (a regulation that received appreciation from many parties) in Gedangsari Subdistrict, efforts to overcome child age marriages have been intensified. Some people are called to play an active role and look for ways to cope with the higher rates of child marriage in Gedangsari Subdistrict in particular and in Gunungkidul District in general. They began to realize that the minimum age requirement for marriage as enshrined in Law Number 1 of 1974 concerning Marriage must be applied for. In the Marriage Law it is stated that the minimum age for someone who wants to get married is 19 years for men and 16 years for women. This limit is violated by many children of the age of marriage. In addition, they also began to realize that if the child's age marriage in Gedangsari Subdistrict continues to be allowed it would endanger the child, especially girls. The born generation is also vulnerable because their parents are not ready physically, psychologically, economically, and socially. This unpreparedness causes families to be the result of the age-old marriage of children vulnerable to domestic violence and divorce; trapped in poverty due to low levels of education; medical risk in women.

The question, from where and from which legal awareness as a social engineering tool arises cannot be ascertained. However, there are some parties who cannot be ruled out in an effort to reduce the marriage rate of children in Gendangsari Subdistrict - those in question are those who consistently work hard from the start until the formation of various sector agreements in overcoming various social problems in Gedangsari District (2013) and the Gedangsari SubDistrict Declaration to prevent child marriage (2014). The non-governmental organization is Rifka Annisa - an organization in Yogyakarta worth mentioning here. This organization that is concerned with gender justice and women's protection has become the first organization that seeks to initiate the management of child age marriages in Gedangsari District. This was told by Suharti, now Director of Rifka Annisa, and Ani Rufaida, in an article entitled "Gedangsari Award".33

In 2012, the activists of Rifka Annisa decided to observe the social conditions of the people in Gedangsari District. They found a number of social problems, such as high rates of poverty, divorce, domestic violence, juvenile delinquency, and child marriage. For the case of child age marriage, at that time it reached 15 cases. This prompted them to form a "young and youth family intervention group" in Ngalang Village and Mertelu under the "Care for Men" program. This program was followed by the equal greeting program (Strengthening and Advancing Children Protection against Sexual Violence) in collaboration with Gedangsari Vocational School. When carrying out its

${ }^{33}$ See: http://www.rifka-annisa.org/id/berita/blog/item/514-gedangsari-award. Accessed on November 30, 2018. 
programs, Rifka Annisa activists had the opportunity to meet with stakeholders in Gedangsari Subdistrict, one of which was Yosep Muniri, Head of the Gedangsari Office of Religious Affairs (KUA) who served since 2013 who was also one of those directly involved in the Integration of Law program Elimination of Domestic Violence and the Law on the Protection of Children into Implementing Institutions for Islamic Marriage Law in 2012. Yosep Muniri is a person who is capable of cooperating with many parties to commit to prevent various forms of violence against women and child marriage in Gunungkidul Regency ccording to the program targeting the involvement of the Office of Religious Affairs (KUA), the Religious Courts, and the Marriage Advisory,Development and Conservation Center (BP4).

Muhammad Thanthowi explained that social problems in Gedangsari Subdistrict in particular and Gunungkidul District generally continued to be discussed in official forums. So, it can be said that there is an effort from community organizations - in this case Rifka Annisa - collaborating with stakeholders - in this case Religious Affairs Office of Gedangsari - in intensive chat that leads to the realization of strategic steps to solve various social problems in Gedangsari District. In this case, the contribution of Yosep Muniri in discussing and cooperating with various institutions in Gedangsari District is quite large. ${ }^{34}$

Talks of some activists from Rifka Annisa and Yosep Muniri with various other stakeholders led them to more intense and more structured talks. Various discussions were carried out both culturally and structurally in a more systematic format. Muhammad Thanthowi stated that one important aspect of efforts to overcome various social problems in Gedangsari District was the involvement of all relevant sectors or institutions. This is the first thing to do is that inter-institutions give an understanding that these problems cannot be solved by one party alone. This awareness was also carried out at the meetings attended by various sectors or institutions in Gedangsari District.At a crosssectoral meeting in all sub-districts in the 2013 Gedangsari Public Health Center II UPT, discussions about mapping and managing various social problems in Gedangsari District were re-raised and discussed. This meeting then produced a recommendation for a Mini Workshop ${ }^{35}$ which specifically discussed various social issues in Gedangsari Subdistrict. Not long after the Mini Workshop was

${ }^{34}$ Based on an Interview with Marwatahadi on Friday August 31, 2018 at 14.00-15.00 WIB in the Gedangsari Sub-District Room; interview with Muhammad Thanthowi on September 4, 2018 at 12.00-13.00 WIB in Wonosari, Gunungkidul Regency; interview with Tugiman, Mertelu Village Chief, on Monday August 27, 2018 at 2:00 p.m.-15: 30 at Tugiman's house in Mertelu Kulon, RT. 03 RW. 02 Mertelu Village, Gedangsari District.

${ }^{35}$ The Mini Workshop is a tribal activity at the Gedangsari II Health Center UPT led by the Head of Gedangsari Health Center II drg. Dyah Mayun Hartanti and was attended by the Muspika of the District of Gedangsari, the Head of the District of Gedangsari District, Posyandu Cadre, and invited guests. 
held at UPT Puskesmas II Gedangsari. This activity was led directly by Dyah Mayun Hartanti, Head of UPT Puskesmas II Gedangsari. On that occasion, Dyah Mayun Hartanti conveyed various social problems in Gedangsari Subdistrict, one of which was the age marriage of children. ${ }^{36}$

At this meeting, each sector presented social problems that occurred in Gedangsari District. Regarding the high marriages at the age of the child, this is admitted by Marwantahadi, the current Head of Gedangsari District. Marwantahadi explained that, when the Mini Workshop was held, the child marriage age rate from year to year seemed uncontrollable. ${ }^{37}$ Marwatahadi's statement was supported by the fact that in 2012, there were 15 child-age marriages (according to Rifka Annisa's findings) and 10 cases (according to data found by Religious Affairs Office of Gedangsari). ${ }^{38}$ The high rate of child marriage is also a concern for Dyah Mayun Hartanti, Head of the Gedangsari II Health Center Unit. Marriage of the age of children, menurtnya, has caused the number of babies born in conditions of low weight. This is caused by the reproductive organs of women who are not medically ready. ${ }^{39}$

The problem that is also of concern is the complexity of the child's age marriage. Child age marriage problems do not stand alone, but involve many factors. One of the educational factors. The high school dropout rate contributes to the number of child age marriages. In some cases, school dropouts have no choice but to get married. Poverty is also another factor in the occurrence of child marriage. It is not uncommon for parents to marry off their children - even by way of force - so that the family burden decreases. What's more, applying for the child is a rich family. Cultural factors also drive the age of children. Many parents think that if they reject a man's proposal, his daughter can become an old maid. Therefore, when the girl is applied for, the parents will accept it, even though her child's age is not enough to get married. In addition, juvenile delinquency can also lead to child marriage. A woman who is pregnant due to promiscuity is forced to marry, even though she is not old enough. ${ }^{40}$

Often teenagers play in areas far from the crowd. This gives a great opportunity for relations to occur like husband and wife. From this promiscuity,

\footnotetext{
${ }^{36}$ Interview with Dyah Mayun Hartanti on Friday, August 31, 2018 at 10.52-11.45 WIB at the Gedangsari II Health Center, Gedangsari District, Gunungkidul Regency.

${ }^{37}$ Interview with Marwatahadi on Friday August 31, 2018 at 14-00-15.00 WIB in the Gedangsari Sub-District Room.

${ }^{38}$ The difference in the age rate of child marriage is not yet known. However, Rifka Annisa's findings can be justified because of the untidy administration of the KUA Gedangsari before 2013, the year the MoU was signed.

${ }^{39}$ Interview with Dyah Mayun Hartanti on Friday, August 31, 2018 at 10.52-11.45 WIB at the Gedangsari II Health Center, Gedangsari District, Gunungkidul Regency.

${ }^{40}$ Interview with Marwatahadi on Friday August 31, 2018 at 14-00-15.00 WIB in the Gedangsari Sub-District Room.
} 
it is not uncommon for pregnancies outside of legal marriages to occur. ${ }^{41}$ The complexity of the various problems made all parties interested to find ways to overcome them. One of the participants of the Mini Workshop, Yosep Muniri, Head of the Office of Religious Affairs (KUA) Gedangsari, suggested that these problems be solved simultaneously involving all sectors. According to him, the social problems in Gedangsari Subdistrict cannot be resolved by one party only, but must involve all relevant institutions. ${ }^{42}$ Yosep Muniri then proposed that a Memorandum of Understanding (MoU) be made or a cross-sectoral agreement in Gedangsari District as a concrete step to resolve these issues. ${ }^{43}$

The making of the MoU was intended so that the implementation of the program could run more effectively. As a matter of fact, there are already institutions in Gedangsari Subdistrict that take care of various social problems that occur, but these institutions have not been integrated, and this is thought to make implementing various programs less effective. In order for this integration and effectiveness to be realized, Yosep Muniri proposed making a cross-sectoral MoU. ${ }^{44}$ Yosep Muniri's proposal was agreed upon by all parties at the Mini Workshop and at the same time marked a new round of efforts to overcome various social problems in Gedangsari District.

Cross-sector commitments were also built taking into account the complexity of the problems in Gedangsari District. These issues are interrelated with the various sectors. From a structural standpoint, the social problems in Gedangsari require a complete solution by each element of the structure, for example, a structure that deals with education, health, social, religious, administrative, and security. The synergy and integration of steps from each of these sectors is expected to be a big step in Gedangsari Subdistrict so that the solution to these various social problems can run well.

Cross-sector commitment was also accompanied by intensive communication with other stakeholders in Gedangsari District. Narratives built across sectors - but still limited to the Gedangsari II Health Center UPT domain - taken to a wider area of Gedangsari District. Communication with the SubDistrict Head and Sub-District Head of Gedangsari Sub-district was built and intensified so that the discourse on the drafting of the Memorandum of Understanding (MoU) was known to all stakeholders in Gedangsari District. One

\footnotetext{
${ }^{41}$ interview with Dyah Mayun Hartanti on Friday, August 31, 2018 at 10.52-11.45 WIB at Gedangsari II Public Health Center, Gedangsari District, Gunungkidul Regency

${ }^{42}$ Interview with Dyah Mayun Hartanti on Friday, August 31, 2018 at 10.52-11.45 WIB at the Gedangsari II Health Center, Gedangsari District, Gunungkidul Regency..

${ }^{43}$ Interview with Yosep Muniri on Friday, August 27, 2018 at 10.30-11.25 WIB in Kepek Hamlet, Wonosari District, Gunungkidul Regency.

${ }^{44}$ Processed from interviews with Dyah Mayun Hartanti on Friday, August 31, 2018 at 10.52-11.45 WIB at the Gedangsari II Health Center, Gedangsari District, Gunungkidul Regency and an interview with Yosep Muniri on Friday, August 27, 2018 at 10:30 to 11:25 WIB in Kepek Hamlet, Wonosari District, Gunungkidul Regency
} 
of the socialization forums at the sub-district level is the Gedangsari Muspika (District Leadership Conference). The forum in which there were Camats, Kepolsek, and Danramil, was also attended by relevant institutions such as stakeholders at the village level and invited guests. It was here that socialization of the needs and preparation of the Memorandum of Understanding (MoU) in Gedangsari District was expected to be an effective means of resolving various social problems in Gedangsari District. Muspika can only refer to maturation from a series of processes that were undertaken before the MoU was signed. Based on the statement of Tugiman, Mertelu Village Chief, there was no refusal from each village about the plan to make the Memorandum of Understanding (MoU). Instead, they feel challenged to realize what is desired in the Memorandum of Understanding (MoU). They welcomed the presence of the Memorandum of Understanding (MoU) because it would be able to make the community progress and prosper..$^{45}$

The new round of tackling various social problems - including child age marriage - began when each sector was committed to making the cross-agency suitability in solving problems in Gedangsari District. This new round was marked by the drafting of a Memorandum of Understanding (MoU) across institutions in Gedangsari District. As mentioned above, the idea of making the MoU was first made by Yosep Muniri in a mini workshop held at the Gedangsari II Health Center. To launch the Memorandum of Understanding (MoU), Yosep Muniri was appointed as Chair of the Draft Draft Team for the Memorandum of Understanding (MoU). Yosep Muniri then took Rifka Annisa so that the communication of Yosep Muniri and the drafting team of the Memorandum of Understanding (MoU) with Rifka Annisa was more intensive. The collaboration between the Draft Compilation Team and Rifka Annisa also showed a considerable role from organizations concerned with gender justice and women's protection in drafting. The time of drafting also does not take too long. There were recorded about four meetings with Rifka Annisa until the draft was completed. ${ }^{46}$

Right on Tuesday, July 2, 2013, at the Gedangsari District Hall, it was signed "Joint Agreement on the Control of Social Problems and Improving the Quality of Marriage and Households in Gedangsari District, 2013 Gunungkidul Regency". ${ }^{47}$ The Memorandum of Understanding (MoU) was made to: (1) realize households that are physically and mentally healthy towards a sakinah family; (2) reduce and prevent maternal and infant deaths and give birth to

${ }^{45}$ Interview with Tugiman, Mertelu Village Chief, on Monday August 27, 2018 at 2:00 p.m.15: 30 at Tugiman's House in Mertelu Kulon, RT. 03 RW. 02 Mertelu Village, Gedangsari District.

${ }^{46}$ Interview with Yosep Muniri on Friday, August 27, 2018 at 10.30-11.25 WIB in Kepek Hamlet, Wonosari District, Gunungkidul Regency.

47"Joint Agreement on the Management of Social Problems and the Improvement of the Quality of Marriage and Households in Gedangsari Subdistrict, Gunungkidul DIY Regency in 2013 ", documentation, archives obtained from the KUA Gedangsari Officer. 
healthy, intelligent and pious generations; (3) increasing the understanding of prospective brides regarding their main rights and obligations as husband and wife, family functions, reproductive health, pregnant and postpartum health, as well as the health of infants and toddlers so that mothers and babies are healthy and healthy; (4) suppressing premarital pregnancy rates; (5) suppressing divorce and suicide cases; (6) encourage the involvement of men (husbands) in suppressing cases of violence against women and children, and in improving maternal and child health.

In Article 2 the Memorandum of Understanding (MoU) agreed that Health Services for each prospective Bride is one of the pre-marital administrative requirements. Services in the form of general health checks, TT immunization, hemoglobin examination for brides, examinations to (not) pregnancies, blood type examinations, and health counseling. To cope with child marriage, the school (Junior and Senior High School) is required to conduct counseling and assistance for students to work together with those who signed the Memorandum of Understanding (MoU), especially Rifka Annisa, Office of Religious Affairs (KUA) (KUA) of Gedangsari, Health Center (Puskesmas), Family Planning Counselor (PLKB), and Sector Police (Polsek) about the dangers of free association and child marriage.

To increase the understanding of the bride and groom, the Office of Religious Affairs (KUA) must hold a prenuptial course at least 4 times a year in collaboration with relevant parties. It was also regulated, under the coordination of the Gedangsari police chief, that the control of the area was alleged to be a perverted area and other immoral acts; under the Commander of the Army (Danramil), the District Trantib, the Council of Ulama (MUI), and the religious instructors, carried out a joint movement to combat suicide. Meanwhile, in the context of learning and strengthening the economy of the newlyweds' families, every bride is required to plant productive trees: 5 banana trees; 5 srikaya trees; and 5 teak trees. The costs of this MoU are supported by the respective Budget Implementation List (DIPA) whose proportion is in accordance with the results of deliberation and communication. ${ }^{48}$ The signing of the Memorandum of Understanding (MoU) involved 32 institutions, including the Village Government and Gedangsari Sub-District, schools, police, religious instructors, Religious Affairs Office of Gedangsari, Community Health Center (PUSKESMAS), and Rifka Annisa and was attended by Badingah, Gunungkidul District Regent. ${ }^{49}$

After the signing of the MoU, in fact, criticism emerged from several parties who did not approve the signing of the MoU. They view groups that are

${ }^{48}$ Article 1-8 "Joint Agreement on the Management of Social Problems and Improving the Quality of Marriage and Households in Gedangsari Subdistrict, Gunungkidul DIY Regency in 2013", documentation, archives obtained from the KUA Gedangsari Officer.

49 "Gedangsari Award"See: http://www.rifka-annisa.org/id/berita/blog/item/514gedangsari-award. Accessed on November 30, 2018. 
pro on the $\mathrm{MoU}$ as a barrier to marital worship. However, the parties pro-MoU remained committed because according to them, the MoU was good and could be a means of overcoming various social problems. ${ }^{50}$ So, after the MoU was signed, the homework for the bearers of the MoU was to apply it.

Religious Affairs Office of Gedangsari in collaboration with Rifka Annisa held a prenuptial course attended by 40 bride and groom couples. In the course discussed the nature of marriage, healthy relations between husband and wife, being good parents, childcare, and women's reproductive health. Gedangsari Religious Affairs Office of and Gedangsari II Tehnique Implementation Unit (UPT) in collaboration with Junior High School (SMP) and Vocational School (SMK) in the Gedangsari Sub-District area held outbound activities that contained sexual and reproductive health material, juvenile delinquency, and understanding of child marriage. ${ }^{51}$ Outbound is made as attractive as possible to attract the interest and enthusiasm of the participants. Various materials were delivered through games (games) that were fun and made it easier for participants to understand. Outbound can even be done twice a year in schools. This activity is fairly successful because teens begin to realize the importance of reproductive health and the dangerous age of child marriage.

Other sectors also carry out their functions to assist in the maturation program of the marriage age. The school - principals, Guidance and Counceling (BP), and other devices - have a role in providing education and training for their students; Health Center (Puskesmas) is responsible for various training and mentoring agenda for students related to sexual and reproductive health; the Office of Religious Affairs (KUA) has the role of providing counseling; security forces have the role of disciplining and combing areas that are places of obscenity and other immoral acts; and community and religious leaders were also involved so that in the various forums he visited talked about the dangers of child marriage. These roles are integrated and synergized with each other..$^{52}$

On Tuesday, March 4, 2014, to strengthen the implementation of the MoU, "Gedangsari Hamlet Declaration" was carried out to prevent child marriage in Gedangsari Subdistrict. The declaration which was followed by all hamlets in Gedangsari Subdistrict was the commitment of the dukuh "to increase public awareness efforts in order to prevent the occurrence of child marriage" and "ready to guide and direct each married couple in Gedangsari as of April 2014 to plant quality bananas and support Gedangsari sub-district is the center of banana as a raw material for household industry activities ". "Gedangsari Yes,

\footnotetext{
${ }^{50}$ Interview with Muhammad Thanthowi on September 4, 2018 at 12.00-13.00 WIB in Wonosari, Gunungkidul Regency.

51 “Gedangsari Award"See: http://www.rifka-annisa.org/id/berita/blog/item/514gedangsari-award. Accessed on November 30, 2018. Plus ...

${ }^{52}$ Interview with Marwatahadi on Friday August 31, 2018 at 14.00-15.00 WIB in the Gedangsari Sub-District Room.
} 
Early Marriage No, Plant Banana Yes". ${ }^{53}$ With the declaration, stakeholders in the hamlet will be more active in trying to reduce the age of child marriage in their area. Dyah Mayun Hartanti said that the declaration was based on the fact that the parties who were always in touch with residents were the village head or hamlet. ${ }^{54}$

In its implementation in the field, various forums - both formal and informal - are used as a means for relevant parties in each hamlet to socialize and direct the community to suppress child marriage. In hamlet (dukuh) meetings, for example, information related to child marriage matters is conveyed. Also when there are programs initiated by the community, such as recitation, information about the child's age marriage is also encouraged. If there are cases where there is a high potential for child marriage, the village head will try to prevent it in various ways including working with other sectors or institutions. ${ }^{55}$

In addition to the village heads and hamlets who are aggressively socializing the issue of child age marriage, other institutions are also involved in handling this problem. Gedangsari the Office of Religious Affairs (KUA) (KUA), for example, cooperates with Rifka Annisa to open counseling services on a weekly basis. The Puskesmas also cooperates with Rifka Annisa to run prevention programs at schools, organizes classes for mothers, fathers and adolescents, various efforts to increase the capacities of stakeholders. Rifka Annisa continues to regularly monitor the implementation of the Momerandum of Understanding $(\mathrm{MoU}) .56$

One of the keys to the success of the child age marriage prevention program in Gedangsari Subdistrict, according to Tugiman, is the synergy between institutions. Each institution complements and supervises each other. This synergy provides a healthy climate in inter-institutional relations, so that each sector is not selfish. Instead, each of these institutions greet and remind each other. ${ }^{57}$ Efforts to prevent child age marriage that are integrated and involve many sectors have positive implications for the level of education of citizens. At least this was stated by Tugiman, Mertelu Village Chief. According to him, this program helped increase the education level of adolescents in Gedangsari

53“" Declaration of Gedangsari Hamlet Tuesday 4 March 2014 ", documentation, archives obtained from employees of KUA Gedangsari.

${ }^{54}$ Interview with Dyah Mayun Hartanti on Friday, August 31, 2018 at 10.52-11.45 WIB at the Gedangsari II Health Center, Gedangsari District, Gunungkidul Regency.

55 "Gedangsari Award" See: http://www.rifka-annisa.org/id/berita/blog/item/514gedangsari-award.

Accessed on November 30, 2018.

56 "Gedangsari Award" Lihat: http://www.rifka-annisa.org/id/berita/blog/item/514gedangsari-award. Accessed on November 30, 2018.Accessed on November 30, 2018.

${ }^{57}$ Interview with Tugiman, Mertelu Village Chief, on Monday August 27, 2018 at 2:00 p.m.15: 30 at Tugiman's House in Mertelu Kulon, RT. 03 RW. 02 Mertelu Village, Gedangsari District. 
District. If before, there were many who only went to junior high school, now it could increase to high school..$^{58}$

\section{Program of Maturation of Age of Marriage: The Decrease of Child Marriage Cases}

Change does not occur without the culprit actors. Anthony Giddens calls them agency. Ali Shariati said it as rausyan fikr - enlightened people or people who are aware of social problems then with all the effort they can do, they try to change and solve these social problems. Based on the previous description, it can be said that many actors are involved in efforts to mature the age of marriage which in turn results in social change in society. They are the people who are aware of it and try to do everything they can to change the unfavorable conditions for the better. Some parties as change actors, among others, firstly, the activists of Rifka Annisa who in 2012 have started activities in Gedangsari District. Secondly, the Office of Religious Affairs (KUA) of Gedangsari Subdistrict - especially Yosep Muniri - who from the beginning oversaw the maturity agenda of the marriage age. These two parties are noteworthy because starting from their cultural conversation, the maturation program of married age was rolled, formulated, and made into a program which would later become a breakthrough in the program to reduce child age marriage in Gunungkidul Regency. Awareness of both parties emerged, because of the intensity of their involvement with the problems of the community in Gedangsari District. If observed from the period of the formation of the MoU on overcoming various social problems in Gedangsari Subdistrict, including the prevention of child marriage, there is a distance of about one year from the first time Rifka Annisa intensively held various social programs in Gedangsari District.

The involvement of Rifka Annisa in the community has raised awareness to further expand the program and its scope so that the effects of the changes also go through. Similar involvement - although in a different case - was experienced by Joseph Muniri. Together with Rifka Annisa, Yosef Muniri often talked about social problems in Gedangsari Subdistrict, including the matter of child age marriage there. Even before meeting intensively with activists Rifka Annisa, Yosef Muniri was involved in the embodiment of various laws and regulations into his institutional programs, which were more or less related to the settlement efforts in Gedangsari District. His involvement in various programs, especially when he could have a lot of dialogue with Rifka Annisa, made him realize to make changes in Gedangsari Sub-District.

The awareness of the activists of Rifka Annisa and the Office of Religious Affairs (KUA) party cannot be seen as mere personal initiation. Rifka Annisa activists the Office of Religious Affairs (KUA) employees are part of the structure

${ }^{58}$ Interview with Tugiman, Mertelu Village Chief, on Monday August 27, 2018 at 2:00 p.m.15: 30 at Tugiman's House in Mertelu Kulon, RT. 03 RW. 02 Mertelu Village, Gedangsari District. 
in their organization. It was here that there was a continuous dialectic between the actors of change and their organizational structure and between the actors and the structure of the community in Gedangsari District. The thoughts and actions of the actors in pursuing social change in Gedangsari Subdistrict are "institutionalized ideas". That is, their thoughts and actions are not only individual actions, but are related to their organization, both programmatically and ideologically.

The change actors work in the structure that governs it. Rifka Annisa works as a community organization to provide guidance and awareness to the community about the dangers of child age marriage, while the Religious Affairs Office (KUA)works as an official government organization in providing services and organizing marriages to create a happy family community that can produce a good generation in the future. The actors of change, with their various thoughts and actions, still work in systems that have been organized but have not been maximally functioned.

This change through the structural path has indeed received much criticism from sociologists, especially those who adhere to the social theory of conflict. That criticism, for example, in terms of whether individuals in an established structure encourage and make significant social changes. If the answer in question is related to total and rapid social change, then that does not happen.

Social change actors in Gedangsari Subdistrict did not take the path of confrontation by holding rival efforts, for example, with existing structures, they did not act outside their structural path. Instead, they seek what can be done through structural channels. Even their thoughts on efforts to prevent child age marriages from the beginning have been orientated to be pursued through a structural path, through the involvement of various stakeholders in Gedangsari District. Thus, the movements of the actors of social change are in structural logic so that the changes will also follow the dynamics of other structures around them. In this context it can also be said that changes in creating new structures, but strengthen existing structures.

The important thing to note is the social problem in Gedangsari District arises because of the lack of functioning of the existing structures that should be responsible for the emergence of social problems. This is what drives these actors to make changes through structural channels, even though at first - the talk of child marriage - only comes from cultural chat. So, it can be said here that the ideas of change from the actors are ideas of structural change. They try to make social changes in a gradual, evolutionary, and targeted way - even though such changes are considered to take a lot of time and energy, while changes are not significant.

Apart from that, as part of the structure of each organization, the actors of change must be appreciated. Rifka Annisa is an organization that is structurally separate from official state organizations capable of playing a role and 
encouraging social change through planning and formulating various regulations concerning the prevention of child marriage. The Office of Religious Affairs (KUA) also deserves appreciation because as a "deep structure" of government organizations they are able to come out and directly capture the social problems that are occurring and contribute to social change in them.

Starting from the cultural conversation between Rifka Annisa and the Office of Religious Affairs (KUA) employees of Gedangsari Sub-District, the social problems in Gedangsari District were echoed and raised to a more serious level, namely a formal forum involving many structures in Gedangsari SubDistrict. Up to this point the ideas of the institutionalized individual were brought and discussed to a broader level of structure, namely the interagency level.

Several institutions were involved intensely in interagency discussions: Office of Religious Affairs (KUA), Rifka Annisa, and Technical Implementation Unit (UPT), Puskesmas Gedangsari II. Talks to overcome various social problems are widespread and involve many institutions. They then agreed to make an agreement to step together to overcome various social problems.

Cultural talks to the involvement of various institutions in tackling child-age marriage problems actually describe the system of adaptation and goal setting of the actors of change. Adaptation and goal setting are two structural functions in Personian theory. A structure if it is said to function, then it must make adaptations and efforts to achieve goals.

Adaptation and achievement of this goal is clearly reflected in the efforts of all parties to commit to reduce and even eliminate the rate of child marriage in Gedangsari Subdistrict. Various state institutions carry out administration, counseling, guidance, and awards to villages that have succeeded in reducing the number of child marriages in adaptation and structural efforts to adapt and make systematic efforts to achieve goals.

Meanwhile, the community began to adjust to comply with various agreements on the prevention of child marriage. If there are people who do not comply, then the relevant institutions will try to take the necessary actions so that the agreement that has been made can be implemented. This is also part of adjusting the structure so that the stated goals can continue to be achieved.

The marriage age maturation program also illustrates the integration and latency of various actors and institutions. Before the MoU was signed, the actors of social change in Gedangsari Subdistrict had realized that the goal of reducing child marriage age rates was impossible to achieve if it did not involve related structures. Here the awareness of integration is so strong in all parties involved in efforts to tackle the child's age marriage problem.

Integration is indeed an important part of the sustainability of an ongoing system and is improving itself. In the context of efforts to overcome child age marriages in Gedangsari Subdistrict, the system is created by involving every relevant institution that has responsibility and authority over the world of 
children. These institutions, as mentioned above, are Office of Religious Affairs (KUA), Gedangsari II Health Center, Rifka Annisa, as well as interested parties in Gedangsari District, both from the sub-district, village and hamlet levels.

In this context, what happens with an individual is not only as a person, but as part of the whole. The actors of social change in this case are not pursuing their interests, but are running the whole social system created. What they call the MoU and a set of other rules shows that they are integrating themselves into the patterns or values of a social system which is an integral part of the social structure.

In terms of this integration, of course each individual will merge and not bring their own ego because what is upheld is the agreed structural values. This is clearly illustrated by the various interviews above, where almost all the speakers emphasized inter-individual and inter-agency cooperation in overcoming the problem of child age marriage. What becomes a personal ego and sectoral ego is avoided as much as possible. All work together and walk towards the same goal, namely prevention of child age marriages in Gedangsari District. Integration between parties or institutions in Gedangsari Subdistrict is driven by the fact that social problems are actually related and involve certain social structures and systems. When this structure and system does not work properly, the structural functions are also not good.

Previously, each structure in Gedangsari Subdistrict in the pond had not been integrated in preventing child marriage. This causes structural functions not to work properly. For the actors of social change, it is not an action that takes into account the problem of child marriage. The problem is that each structure or individual works limited to its scope without any communication and shared agenda with other institutions, in other words, there is no integration between institutions. This is what the actors realized, so they arrived at the attitude that there must be inter-agency policies and cooperation which became the umbrella for the creation of inter-institutional integration. This integration will strengthen the structural performance that will or has been built. Integration between these institutions produced results in terms of decreasing the number of child marriages in Gedangsari District. Each of them works together to prevent child marriage so that children and parents can realize the dangers of the marriage. Adolescent association can also be improved a little more through the efforts of security forces combing dirty places, so that education and health parties are intensively conducting coaching. Rifka Annisa and KUA also work in the same agenda. Among all these institutions, as well as other interested institutions, integration occurred so as to create harmony of action in preventing child marriage in Gedangsari Subdistrict.

To maintain the social structure and system that has been built between these institutions, stakeholders in Gedangsari Subdistrict have their own ways. In addition to holding rewards for villages that have succeeded in carving out the zero number of child age marriage cases in their area, each institution has a 
continuous communication system through both official events and cultural communication. Each institution reminds each other of the integration between institutions to continue to run.

This was clearly illustrated in the statements of the sources which emphasized the existence of intensive communication between them to keep reminding each other and advising on efforts to prevent the age marriage of the child. If needed, they will support each other in practice when there is a case of child marriage. Cross-sector communication and coordination systems are built through official and informal forums. They also use information technology to facilitate communication. There are special social media groups that are formed so that communication and coordination remain smooth.

\section{Program of Maturation as Legal Rationalization and Eenforcement within Society}

Based on the engineering process of Islamic law enforcement in the form of maturing marital age in Gedangsari Subdistrict, it was found that the program was quite effective in reducing the age of child marriage. The decline can even be called significant. Borrowing Weber's term, this change can be seen from the existing authority system or recognized in Gedangsari District. From here we can explore what factors actually underlie the existence of social change.

Interviews regarding the maturation of the marriage age above indicate that social change in Gedangsari District is closely related to the system of rational-legal authority. The foundation built and disclosed by the informants shows that "bureaucratic rationalization" has begun even though it has not yet been fully implemented. There is a systematic effort by the actors of social change there to rationalize the facts that occur which then encourage them to make changes.

The rationalization in question is in the form of mindset and actions of the actors of change based on habits, rules, and applicable laws. This is clearly illustrated in the descriptions of the sources who rationalized the maturation program of marriage age through various aspects, for example, economics, education, social conditions, health, and culture. For example, from an economic standpoint, child marriage is very likely to contribute to increasing poverty; in terms of education, child age marriage is often caused by a lack of awareness of the dangers of child marriage and dropping out of school; from social conditions, there is adolescent free association which is one of the triggers for child marriage; in terms of health, there is a thought that child age marriage is harmful to reproductive health - especially mothers and children; and in terms of culture, child age marriage is not infrequently based on traditions that are actually irrational. This rationalization was then wrapped up by the existence of a basis for legislation, such as in Law Number 1 of 1974 concerning Marriage. The law in this case is used as a normative reference to show the need for social change. 
Basing on various rational and juridical arguments shows that at a certain level, the organization and bureaucracy in Gedangsari Subdistrict began to develop to become more modern. In modern organizations, organizational decisions and actions are based on systems and clear rules that are agreed upon or determined by the organization or structure above them. In modern organizations, communication and coordination patterns are arranged so that there are no "overlapping" decisions or actions. Maturity age maturation program can also be said to be followed (obeyed) by the people in Gedangsari Sub-District so that there are significant social changes. The problem of child marriage that is high enough decreases sharply. Within a few years, there were even villages that were able to eliminate child-age marital cases in the region. This decrease can be said because of the hard work of each party or institution in preventing the occurrence of child age marriages in Gedangsari Subdistrict. Through various efforts, such as mentoring teenagers and parents, counseling, pre-marital courses, as well as the efforts of interested parties in asking for help in preventing child marriage, the people in Gedangsari Sub-district are beginning to realize the dangers of child marriage. It also shows that the decision to postpone marriage until it reaches sufficient age is based on rational argumentation. Thus, social change that occurs through the maturation program of child-age marriage is more driven by rational-legal authority than traditional and charismatic authorities. Building systems and social structures or more modern organizations in Gedangsari Subdistrict are believed to be the reason for the community to base their decisions on delaying child age marriages on rational reasons. The awareness raising was carried out by various institutions.

\section{Concluding Remarks}

Based on the above description, the following points can be concluded: first, the maturation program of marriage age in Gedangsari Subdistrict is a program that is held to prevent the occurrence of child marriage by involving various organizations and related sectors / institutions. Secondly, the maturation program of mating age has so far been very effective in reducing the rate of child marriage in Gedangsari Subdistrict. Third, the provision of a marriage age maturation program can be interpreted as social engineering so that social change takes place in the community through the process of adaptation, efforts to achieve goals, integration and latency of systems and social structures. Social engineering through law enforcement is built on rational and legal (rationallegal) arguments.

\section{Bibliography}

"Angka Partisipasi Murni (APM) dan Angka Partisipasi Kasar (APK) Menurut Jenjang Pendidikan di Kabupaten Gunungkidul, 2015, 2016" http//:gunungkidulkab.go.id.

Ariananto, Satya dan Ninuk Triyanti, Memahami Hukum: Dari Konstruksi Sampai 
Implementasi, Jakarta: Rajawali Press, 2011.

Azhari, Fathurrahman. "Dinamika Perubahan Sosial dan Hukum Islam", Jurnal At-Tahrir , Vol. 16, No. 1 (May 2016): 198-207.https://doi.org/10.21154/altahrir.v16i1.322

Azra, Azyumardi, Pergolakan Politik Islam dari Fundamentalisme, Modernisme, hingga Post-Engineering, Jakarta: Paramadina, 1996.

Central Bureau of Statistics of Gunungkidul Regency, Gunungkidul Regency in Figures 2018, Yogyakarta: Gunungkidul Regency Central Bureau of Statistics, 2017- 2018.

Central Bureau of Statistics of the Special Province of Yogyakarta, People's Welfare

Statistics (Welfare Statistics) 2010-2017, Yogyakarta: Badan Pusat Statistik Daerah Istimewa Yogyakarta, 2010-2017.

Darmaningtyas. Pulung Gantung: Menyingkap Tragedi Bunuh Diri di Gunungkidul, Yogyakarta: Salwa Press, 2002.

"Declaration of Dukuh Gedangsari Selasa 4 Maret 2014", documentation, archives obtained

from employees KUA Gedangsari.

Dewi, Novita "Pengantin-Pengantin Bocah Dalam Sastra Berlatar Di Indonesia, Afghanistan,Dan Bangladesh", Jentera: Jurnal Kajian Sastra, 7 (2) 2018, 127144. (https://doi.org/10.26499/jentera.v7i2.876)

Djasmani, H. Yacob, "Hukum sebagai Alat Rekayasa Sosial dalam Praktik Berhukum di Indonesia", Jurnal Masalah-Masalah Hukum, Vol. 40 No. 3 Tahun 2011: 365374. 10.14710/mmh.40.3.2011.365-374

Ergene, Bogac A. "Islamic Law in Action: A Historical Discussion" Law and Social Inquiry, Vol. 38, No. 4, (2013): pp. 1041-1042. https://doi.org/10.1111/lsi.12046

Fakih, Mansour, Analisis Gender dan Tranformasi Sosial, Yogyakarta: Pustaka Pelajar, 1996.

Fitriyani, Ab Basir Laupe, "Positivisasi Hukum Islam dalam Pembinaan Hukum Nasional di Indonesia" Al-Ulum (Jurnal Studi Islam), Vol. 13, No. 2, (Desember 2013): pp. 457.

Friendman, Lawrence M. , Sistem Hukum: Perspektif Ilmu Sosial, Bandung: Nusa Media, 2009.

Gunungkidul Regency Population and Civil Registration Office, Profile of Population Development in Gunungkidul Regency, 2017 Yogyakarta: Disdukcapil Kabupaten Gunungkidul, 2017.

Gunungkidul Regent Regulation No. 36 of 2015 concerning Prevention of Marriage at the

Age of Children.

Gurvitch, Georges. Sociology of Law. London: Open University, 1947.

Hanafi, Yusuf, Kontroversi Perkawinan Anak di Bawah Umur (Child Marriage), Bandung: Mandar Maju, 2011. 
ADHKI: Journal of Islamic Family Law

Hidayat, Fatah, "Dinamika Perkembangan Hukum Keluarga di Indonesia, dalam Jurnal An Nisa" Vol. 9, No. 2, (December 2014): pp. 1-14.

Jalaluddin Rakhmat, rekayasa sosial: Reformasi, Revolusi, atau Manusia Besar, Bandung: Remaja Rosdakarya, 2000

Junaidi, Nidya Putri Syahida, Nuraini, "Fenomena Pernikahan Dini Di Desa Loloan Kecamatan Bayan Kabupaten Lombok Utara", JIAP, Jurnal Ilmu Administrasi, Vol. 7 No. 1 Maret 2019, Hal. 34-43.

Kansil, C.S.T. Pengantar Ilmu Hukum dan Tata Hukum Indonesia. Jakarta: Balai Pustaka, 1989.

Komisi Yudisial Republik Indonesia. Menimbang Ulang Hukum sebagai Saran Rekayasa Sosial. Jakarta: Sekretariat Jenderal Komisi Yudisial Republik Indonesia, 2012.

"Joint Agreement on Countering Social Problems and Improving the Quality of Marriage

and Households in Gedangsari District, 2013 Gunungkidul Regency", documentation, archives obtained from Gedangsari KUA Officer.

Koro, Abdi, Perlindungan Anak di bawah Umur dalam Usia Perkawinan Usia Muda dan

Perkawinan Siri, Bandung: Alumni, 2012.

Kuthby, Moh. Habib Al- "Dampak Perkawinan di Bawah Umur terhadap Hubungan dalam Rumah Tangga (Studi Kasus di Desa Purwodadi Kecamatan Tepus Kabupaten Gunungkidul Tahun 2010-2013)" Thesis Unpublished, Yogyakarta: Program Pascasarjana, 2016.

Maryani, Enok dan Bagja Waluya, "Hand Out Geography Course in City Village", Bandung: Universitas Pendidikan Indonesia, 2008.

Maula, Bani Syarif, Sosiologi Hukum Islam di Indonesia; Study of the Reality of Islamic Law in Configuring Social and Politics, Yogyakarta: Aditya Media Publishing, 2010.

Megawangi, Ratna, Membiarkan Berbeda? The New Viewpoint on Gender Relations, vol. 1, Bandung: Mizan, 1999.

Moleong, J. Lexy, Metodologi Penelitian Kualitatif, Bandung: Remaja Rosdakarya, 2017.

Mucklis, Imam, “Peran Keluarga terhadap Pernikahan Dini (Studi Kasus Desa Krambilsawit Kecamatan Saptosari Kabupaten Gunungkidul Daerah Istimewa Yogyakarta)" Unpublished Thesis, Yogyakarta: Da'wah Faculty and Communication, 2015.

Praja, Juhaya S, Teori Hukum Dan Aplikasinya, Bandung: Pustaka Setia, 2011.

Rahardjo, Satjipto, Hukum dan Masyarakat. Bandung: Angkasa Bandung, 1986.

-------, Hukum Dan Perubahan Sosial: Suatu Tinjauan Teoritis Serta PengalamanPengalaman Di Indonesia, Yogyakarta: Genta Publishing, 2009.

-------, Sosiologi Hukum Esai-esai Terpilih, Ufran (ed.), Yogyakarta: Genta Publishing, 2010.

Rasjidi, Lili, Dasar-Dasar Filsafat Hukum, Bandung: Citra Aditya, 1990. 
Rasjidi, Lili, dan I.B. Wyasa Putra, Hukum Sebagai Suatu Sistem, Bandung: Mandar Maju, 2003.

Ritzer, George, Teori Sosiologi Modern, terj. Triwibowo B.S. Jakarta: Kencana, 2014.

Rosana, Ellya. "Hukum dan Perkembangan Masyarakat", in Journal TAPIs Vol. 9, No. 1, (Januari-Juni 2013): 109.

Setiyanto, Danu Aris. Hukum Islam Sebagai Rekayasa Sosial Dan Implikasinya Dalam Undang-Undang Perkawinan Di Indonesia, Ijtihad, Jurnal Wacana Hukum Islam dan Kemanusiaan, Vol. 17, No. 2 (2017), pp. 175-189, doi :10.18326/ijtihad.v17i2.175-189

Shaham, Ron. "Custom, Islamic Law, and Statutory Legislation: Marriage Registration and Minimum Age at Marriage in the Egyptian Sharī 'a Courts", Islamic Law and Society, Vol. 2, No. 3, (1995): 258.

Soekanto, Soerjono, Sosiologi: Suatu Pengantar, Jakarta: PT. RajaGrafindo Persada, 1999.

-------,. Pokok-Pokok Sosiologi Hukum. Jakarta: RajaGrafindo Persada, 2013.

-------.,Pendekatan Sosiologi terhadap Hukum, Jakarta: Bina Aksara, 1988.

-------, Fungsi Hukum Dan Perubahan Sosial, Bandung: Alumni, 1981.

"Statistik Penduduk Yogyakarta Special Province", via website kependudukan.jogjaprov.go.id.

Sudantra, I Ketut, I Gusti Ngurah Dharma Laksana, "Di Balik Prevalensi Perkawinan Usia Anak Yang Menggelisahkan: Hukum Negara Versus Hukum Adat",Jurnal IUS Kajian Hukum dan Keadilan, Vol 7, No 1 (2019), Hal. 56-72, DOI : 10.29303/ius.v7i1.594

Sugiyono, Metode penelitian kuantitatif, kualitatif, dan RED, Bandung: Alfabeta, 2017.

Suhadi, Baidhowi, Cahya Wulandari, "Pencegahan Meningkatnya Angka Pernikahan Dini dengan Inisiasi Pembentukan Kadarkum di Dusun Cemanggal Desa Munding Kecamatan Bergas ," Jurnal Pengabdian Hukum Indonesia ( Indonesian Journal of Legal Community Engagement ) JPHI, 01(1) (2018): 31-40

Sukandarrumidi, Metode Penelitian: Petunjuk Praktis Untuk Peneliti Pemula, Yogyakarta: Gadjah Mada University Press, 2012.

Tsany, Fitriana, “Trend Pernikahan Dini di Kalangan Remaja

(Case Study in Gunungkidul Regency, Yogyakarta, 2009-2012)", Jurnal Sosiologi Agama, Volume 9, No. 1, Januari-Juni, 2015.

Law Number 1 of 1974 Concerning Marriage.

Veeger, KJ. Realitas Sosial: Refleksi Filsafat Sosial atas hubungan Individu-Masyarakat dalam Cakrawala Sejarah Sosiologi, Jakarta: Gramedia, 1985. 